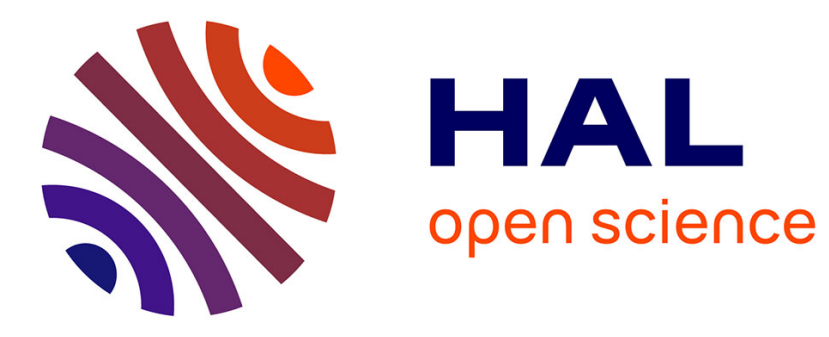

\title{
Modeling of Large Air Gap Transformers Using Magnetic Equivalent Circuit for Designing of High Power Application
}

Jean-Romain Sibue, Jean-Paul Ferrieux, Gérard Meunier, Robert Périot

\section{To cite this version:}

Jean-Romain Sibue, Jean-Paul Ferrieux, Gérard Meunier, Robert Périot. Modeling of Large Air Gap Transformers Using Magnetic Equivalent Circuit for Designing of High Power Application. CEFC 2010 (14th Biennial IEEE Conference on Electromagnetic Field Computation), May 2010, Chicago, United States. pp.978-1-4244-7061-7/10. hal-00484897

\section{HAL Id: hal-00484897 https://hal.science/hal-00484897}

Submitted on 19 May 2010

HAL is a multi-disciplinary open access archive for the deposit and dissemination of scientific research documents, whether they are published or not. The documents may come from teaching and research institutions in France or abroad, or from public or private research centers.
L'archive ouverte pluridisciplinaire HAL, est destinée au dépôt et à la diffusion de documents scientifiques de niveau recherche, publiés ou non, émanant des établissements d'enseignement et de recherche français ou étrangers, des laboratoires publics ou privés. 


\title{
Modeling of Large Air Gap Transformers Using Magnetic Equivalent Circuit for Designing of High Power Application
}

\author{
Jean-Romain Sibué ${ }^{1,2}$, Jean-Paul Ferrieux ${ }^{1}$, Gérard Meunier ${ }^{1}$, Robert Périot ${ }^{2}$ \\ ${ }^{1}$ G2ELAB, ENSE3 - BP46 - 38402 Saint Martin d'Hères \\ ${ }^{2}$ ALSTOM, BP4 - Rue du docteur Guinier, 65601 Séméac Cedex \\ jean-romain.sibue@g2elab.grenoble-inp.fr, jean-paul.ferrieux@g2elab.grenoble-inp.fr, \\ gerard.meunier@g2elab.grenoble-inp.fr, robert.periot@transport.alstom.com
}

\begin{abstract}
This paper presents a model of large air gap transformer composed of two $E$ cores. Approach is based on the magnetic equivalent circuit using reluctance network and considers two and three dimensions phenomena. Thanks to this analytic model, it is possible to determine rapidly and easily electrical parameters of a two windings transformer in order to design such magnetic devices. Finally, 2D and 3D finite elements method are used to demonstrate the accuracy of this model.
\end{abstract}

\section{INTRODUCTION AND RELUCTANCE NETWORK}

Many studies deal with design of transformer with large air gap without magnetic core [1], [2] and present iterative design methods. Similar method can be applied to transformer with large air gap with magnetic core. Sizing of such components requires knowledge of inductive parameters of transformer. It is because an analytic model has a great interest compared to 3D finite elements methods which take longer time.

For this study, the geometry of magnetic core is composed of two $\mathrm{E}$ because they concentrate flux, encircle conductors and limit magnetic attraction. The aim is to deduce the electric equivalent circuit composed of leakage inductance (Lf), magnetizing inductance $(\mathrm{Lm})$ and transformer ratio $(\mathrm{m})$ (Fig.1.b) from geometry of magnetic device. Fig. 1.a shows the reluctance network implemented in the front view of large air
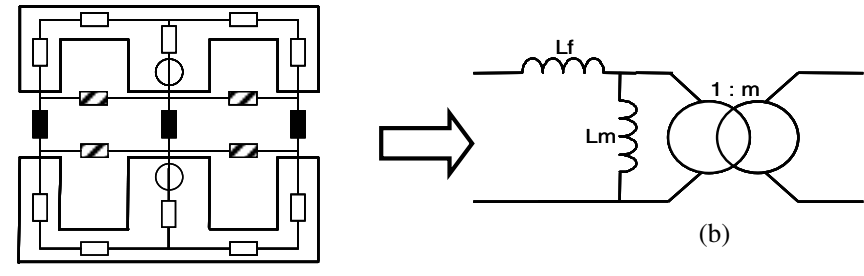

(b)

(a)

Fig. 1. (a) Front view of large air gap transformer with reluctance network. (b) Electrical model of a two windings transformer.

gap transformer composed of two E cores geometry. Reluctance network is the same for 2D and 3D approaches. It is only the equations of different reluctances which change. White, black and hatched reluctances represent respectively magnetic cores, air gap and leakage reluctances.

\section{Reluctance CAlCUlation}

Reluctances of magnetic cores can be easily calculated from general formula. Present reluctances in air can be decomposed in leakage reluctance and air gap reluctance. First are calculated from Ampere's law. Second are more complicated to estimate because it is necessary to consider fringing effect. Two methods are compared to describe this phenomenon: Schwarz-Christoffel transformation [3] and integral calculus of permeance (inverse of the reluctance) from flux path (supposed known) [4]. Different flux path lengths have been tested: straight plus semicircle, circle and ellipse. From 2D model, it is easy to deduce the 3D model by associating basic reluctances in parallel.

\section{VALIDATION MODEL}

To validate models, 2D and 3D finite elements methods are used (FLUX2D ${ }^{\circledR}$ and FLUX3D ${ }^{\circledR}$ ). All models give a good accuracy in 2D for low air gap (Fig. 2). When air gap

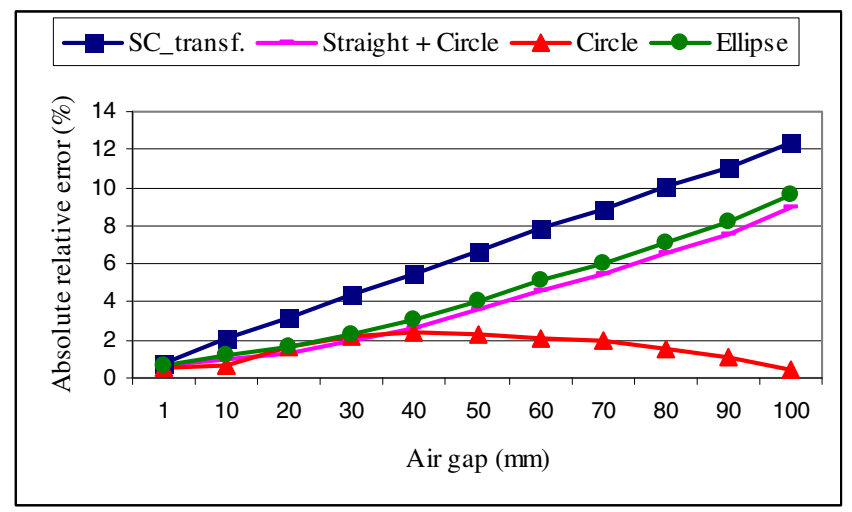

Fig. 2. Absolute relative error of 2D analytic models versus air gap.

increases, accuracy decreases except for the case where flux path is considered as circle (absolute relative error does not exceed 3\%). In 3D approach, model allows to reach a good accuracy to design this kind of magnetic components for large air gap.

In spite of simplicity of reluctance network, the accuracy and validity slop are sufficient to allow 3D sizing of a large air gap transformer. This model has been implemented in iterative design method to size a large air gap and high power transformer. Designing is fast and accurate.

\section{REFERENCES}

[1] J. Sallan, J. L. Villa, A. Llombart, J. F. Sanz, "Optimal design of ICPT systems applied to electric vehicle battery charge", IEEE Trans. Ind. Electron., vol. 56, pp. 2140-2149, June 2009.

[2] O. H. Stielau, and G. A. Govic, "Design of loosely coupled inductive power transfer systems", in Proc. 2000 Int. Conf. Power System Technology, Vol. 1, pp. 85-90, December 2006.

[3] A. Balakrishnan, W. T. Joines, and T. G. Wilson, "Air-Gap Reluctance and Inductance Calculations for Magnetic Circuits Using a SchwarzChristoffel Transformation," IEEE Transactions on Power Electronics, Vol. 12, No. 4, pp. 654-662, July 1997.

[4] J. Cale, S. D. Sudhoff, and L. Q. Tan, "Accurately Modeling EI Core Inductors Using a High-Fidelity Magnetic Equivalent Circuit Approach", IEEE Transactions on Magnetics, Vol. 42, No. 1, pp. 4046, January 2006. 